\title{
Cytotoxic and antioxidant effects of grape seed oil on the treatment of leukemia with methotrexate
}

\author{
Nefise Ozlen Sahina,*, Mehmet Berközb, Ebru Derici Ekera, \\ Bartosz Pomiernyb,c and Katarzyna Przejczowskab,c \\ a Mersin University, Faculty of Pharmacy, Department of Pharmaceutical Biotechnology, Mersin, TR-33169, Turkey \\ b Mersin University, Faculty of Pharmacy, Department of Pharmaceutical Technology, Mersin, TR-33169, Turkey \\ c Jagellonian University, Medical College, Krakow, 30-688, Poland \\ ${ }^{*}$ Corresponding author at: Mersin University, Faculty of Pharmacy, Department of Pharmaceutical Biotechnology, Mersin, TR-33169, Turkey. \\ Tel.: +90.505.6636274; fax: +90.324.3413022. E-mail address: nefisesahin@gmail.com (N.O. Sahin).
}

\section{ARTICLE INFORMATION}

Received: 07 November 2011

Received in revised form: 15 December 2011

Accepted: 18 December 2011

Online: 30 June 2012

\section{KEYWORDS}

Leukemia

Cytotoxicity

Methotrexate

K562 cell line

Grape seed oil

Oxidative stress

\section{ABSTRACT}

Methotrexate (MTX), a widely used cytotoxic chemotherapeutic agent, is often limited by its severe toxicity. Regarding the mechanisms of its adverse effects, several hypotheses have been put forward, among which oxidative stress is highly noticeable. Additive effect of oxidative damage caused by MTX to oxidative stress induced by cancer makes the situation dramatically bad. In order to reduce the damage, several approaches have been suggested. Grape seed is one of the most significant prophylactic agents due to its antioxidant and bioflavonoids composition. The aim of this study was to investigate the protective effect of grape seed oil against MTX-induced oxidative stress in K-562 human chronic myeloid leukemia cell lines. Cells were divided into groups as following control, GSOH (tumor cells treated with $200 \mu \mathrm{g} / \mathrm{mL}$ of grape seed oil), GSOL (tumor cells treated with $100 \mu \mathrm{g} / \mathrm{mL}$ of grape seed oil), MTX (tumor cells treated with $50 \mathrm{nM}$ methotrexate) and MTX + GSOH ( tumor cells treated with $200 \mu \mathrm{g} / \mathrm{mL}$ of grape seed oil and methotrexate). For antioxidant statue; superoxide dismutase (SOD), catalase (CAT), paraoxonase (PON) and aryl esterase (ARE) activities, for lipid peroxidation; malondialdehyde (MDA) level and also for cytotoxicity; cell viability were detected in $24^{\text {th }}$ and $48^{\text {th }}$ hours of the cell culture incubation. Based on the data, $200 \mu \mathrm{g} / \mathrm{mL}$ of grape seed oil indicates synergic effects with MTX on K562 regarding cytotoxicity especially in $48^{\text {th }}$ hour. In case of GSOH + MTX combined treatment for 24 hours, antioxidant system take part preventing lipid peroxidation and a possible oxidative damage. Upon 48 hour-GSOH treatment, antioxidant parameters show significant increase and hence, prevent lipid peroxidation in cancer cells. In conclusion, GSOH complimentary treatment may be suggested for leukemia therapy with MTX to reduce side effects and enhance the cytotoxicity of MTX.

\section{Introduction}

Number of clinical evidences on therapeutic efficiency of high dose chemotherapeutic administration has been significantly increasing every day. However, even the most efficient use of chemotherapeutic drug applications is limited due to its serious damage to noncancerous healthy tissues [1]. Methotrexate (MTX), a widely known chemotherapeutic agent, has been successfully used in the treatment of various forms of rheumatological and dermatological diseases as well as various cancer types (e.g. solid organ tumors and leukemia). Furthermore, low dose MTX administration has been applied to cure some autoimmune diseases such as psoriasis and rheumatoid arthritis [2]. MTX, an antimetabolite and a folic acid antagonist, can cause unpredictable serious side effects [3]. Mechanism of the side effects is not clear, yet. However, it's assumed that the main reason is related to the oxidative stress occurring during the biotransformation in liver [2-4].

Daily combinational use of folic acid with MTX has been widely suggested by physicians as it reduces hepatic toxicity of the drug with its antioxidant properties [5]. However, it is still contraversial whether the use of folic acid reduces therapeutic efficiency of MTX or not [2,5]. Therefore, new antioxidant agents have been put on experimental trials against systemic oxidative damage caused by MTX [6-8]. Among these agents, $\mathrm{N}$ acetylcystein and glutamine showed useful effect on the oxidative damage caused by MTX in some tissues with high proliferation rate [6-8]. Some researchers reported that Lcarnitine, $\mathrm{N}$-acetylcysteine, taurine, melatonine, garlic, urodeoxycholic acid and grape seed play protective role against the systemic oxidative damage of MTX due to their antioxidant properties $[2,9]$.

Grape seed with antioxidant properties is sold in Turkish market in the form of extract or oil [10,11]. It was proven that grape seed with radical scavenger activity possesses much stronger protective effect against free radicals than those of vitamin C and E [12-16]. Resveratrol in grape seed is a natural compound preventing cell proliferation in leukemia, prostate, breast, and other types of cancers. It also possesses antimycotic, antineoplastic, antioxidant, antiproliferative, and anti-inflammatory effects [15,17-26].

In this study, it was aimed to investigate cytotoxicity and antioxidant effect of single or combinational use of grape seed oil with MTX in treatment of K562 chronic myeloid leukemia 
cells under in vitro conditions. The effect of concentration was tested at various time intervals.

\section{Experimental}

\subsection{Cell line and cell culture}

In this study, K562 cells of human chronic myeloid leukemia cell line were used. The cell line was generated and kindly provided by Hacettepe University, Faculty of Medicine, Department of Medical Biology and Genetics. The cells were proliferated in culture mediums under in vitro conditions for adaptation. K562 cells were incubated in RPMI-1640 (Sigma, St, Louis, MO, USA) medium supplemented with \% 15 fetal calf serum (Sigma, St. Louis, MO, U.S.A.), $10.000 \mathrm{U} / \mathrm{mL}$ penicillin (Sigma, St. Louis, MO, U.S.A.), $10 \mathrm{mg} / \mathrm{mL}$ streptomycin (Sigma, St. Louis, MO, U.S.A.), $0.025 \mathrm{mg} / \mathrm{mL}$ Amphotericin B (Sigma, St. Louis, MO, U.S.A.) and $0.3 \mathrm{~g} / \mathrm{L}$ L-Glutamine (Sigma, St. Louis, MO, U.S.A.) at $37 \pm 0.5^{\circ} \mathrm{C}$ in an incubator containing $5 \% \mathrm{CO}_{2}$ (Biolab, USA). $\mathrm{pH}$ of the medium was adjusted to 7.0-7.4 and kept constant throughout the experiment. Culture mediums were changed three times in a week. Upon reaching sufficient live cell number, they were passaged at the ratio of $1: 3$ to obtain a cell collection for the project.

These K562 cell collections were divided into five groups. Each group had seven parallel cell lines. The first group was assigned as the control group and contained untreated K562 cells. The second group was called as GSOH group in which K562 cells were treated with high concentration of grape seed oil $(200 \mu \mathrm{g} / \mathrm{mL})$. The third group was named as GSOL group which was composed of K562 cells treated with low concentration $(100 \mu \mathrm{g} / \mathrm{mL})$ of grape seed oil. The fourth group was methotrexate group (MTX) containing $50 \mathrm{nM}$ methotrexate (Methotrexate ${ }^{\circledR}$-Koçak Farma, Istanbul, Turkey) treated K562 cells. The final group was called "MTX+GSOH" and the K562 cell content of this group was treated with both methotrexate (50 $\mathrm{nM})$ and grape seed oil $(200 \mu \mathrm{g} / \mathrm{mL})$.

Among these groups, the control group was used directly without any further treatment. However, the cells in other four groups were transferred into twenty four- well plate in the density of $1 \times 10^{5}$ cells/ $\mathrm{mL}$ for further treatment with grape seed and/or methotrexate.

\subsection{Cell viability test}

The dye exclusion test was used to determine viable cells after they have treated with various concentrations of grape seed oil and/or MTX at 24th and 48th hour of incubation [27]. Blue stained apoptotic cells were counted under a light microscope (Nikon, Japan). All measurements were repeated for three times in each group. Rate of cytotoxicity was calculated based on the number of apoptotic cells using the below equation:

Cytotoxicity rate (percentage of death cells $)=[$ (number of trypan blue stained cells / total number of cells) x 100]

\subsection{Preparation of cell homogenisates}

In order to determine oxidative stress states of K562 cells in all groups, antioxidant enzyme activity and lipid peroxidation levels were measured. Therefore, catalase (CAT), superoxide dismutase (SOD), paraoxanase (PON), and arylesterase (ARE) activities were determined as enzymatic antioxidant activity. Malondialdehyde (MDA) levels were measured for lipid peroxidation.

In the end of 24 hour-incubation, $1 \mathrm{~mL}$ of the cells in pellets were withdrawn and used for the measurement of antioxidant activity and lipid peroxidation. To stop the cytotoxic effect of chemicals on cells, they were immediately washed with phosphate buffer $(\mathrm{pH}=7.4)$ for three times. Subsequently, $1 \mathrm{~mL}$ of phosphate buffer was added to each sample and then homogenized using a homogenisator with a teflon tip (Heidolph, Germany). The resultant homogenisates were centrifuged at $13.000 \mathrm{rpm}$. Supernatant was removed and stored at $-20^{\circ} \mathrm{C}$ for further analysis. The same procedure was applied in the end of 48 hour-incubation period. Antioxidant activity and lipid peroxidation analysis were performed on all these samples in seven parallel series.

\subsection{Measurement of catalase activity}

CAT activity measurements were conducted according to the method of Aebi et al. [28]. The principal of the method is the monitoring enzymatic degradation of $\mathrm{H}_{2} \mathrm{O}_{2}$ substrate with catalase enzyme at $240 \mathrm{~nm}$. The results were expressed as $\mathrm{U} / \mathrm{mg}$ protein.

\subsection{Measurement of superoxide dismutase activity}

Determination of SOD activity was performed according to the method of Sun et al. [29]. The method is based on the measurement of SOD enzyme activity accelarating dismutation of endogenous and exogenous toxic superoxide radicals to water and molecular oxygen. The principal of the method is the measurement of the absorbed color by the inhibition of nitro blue tetrazolium (NBT) reduction due to $\mathrm{O}_{2}$ generated by the xantine/xantineoxidase system at $560 \mathrm{~nm}$. One unit of SOD activity of cell homogenisates was defined as the amount protein causing $50 \%$ inhibition of the NBT and expressed as $\mathrm{U} / \mathrm{mg}$.

\subsection{Measurement of paraoxanase and arylesterase activities}

Determination of PON and ARE activities were performed according to the method of Eckerson et al. [30]. The basis of the method for PON activity is the spectrophotometric determination of $p$-nitrophenol formation as a result of enzymatic hydrolysis of paroxanase at $412 \mathrm{~nm}$, using $100 \mathrm{mM}$ Tris-HCl buffer $(\mathrm{pH}=8.0)$ containing $2 \mathrm{mM} \mathrm{CaCl}_{2}$ and $4 \mathrm{mM}$ paraoxon.

$2 \mathrm{mM} \mathrm{CaCl} 2$ containing $100 \mathrm{mM}$ Tris- $\mathrm{HCl}$ buffer of $\mathrm{pH}=8.0$ were used for the determination of ARE activity. In this test, phenyl acetate was used as a substrate instead of paraoxone. Formation of phenol as a result of aryl esterase enzymatic hydrolysis was determined spectrophotometrically at $270 \mathrm{~nm}$ using Analytikjena-SPECORD 50 UV/VIS spectrophotometer. One unite of PON activity was expressed as 1 micromole $p$ nitrofenol $/ \mathrm{mL}$ serum $/ \mathrm{min}$ and one unite of ARE activity was defined as $1 \mathrm{micromol}$ phenol/mL serum $/ \mathrm{min}$.

\subsection{Measurement of malondialdehyde level}

The levels of MDA in cell culture samples, as an index of lipid peroxidation, were determined by a thiobarbutiric acid reaction using the method of Yagi [31]. The method is based on the spectrophotometric measurement of pink-red color of the compound formed by MDA and thiobarbutiric acid at $532 \mathrm{~nm}$ as a result of peroxidation of polyunsaturated fatty acids. 1,1,3,3-Tetramethoxypropane was used as standard. Then, density vs. absorbance graph was plotted and linear equation was calculated using regression analysis. Next, absorbance values of cell culture samples were placed into this equation to calculate MDA densities. The resultant values were divided to protein amounts to calculate MDA levels which were expressed as $\mathrm{nmol} / \mathrm{mg}$.

\subsection{Determination of protein content}

The protein contents of the cell culture homogenisates were measured by a procedure similar to that documented by 
Lowry et al. [32] using bovine serum albumin as a standard. The results were expressed as mg.

\subsection{Statistical analysis}

Statistical analysis of the data was carried out employing SPSS v.16.0 program. Data were expressed as mean \pm standard deviation. Values of $\mathrm{p}<0.05$ were regarded as significant. Kolmogorov-Smirnov test was used to evaluate the goodness of fit for normal distribution. Statistical differences among groups were evaluated using ANOVA. Multiple comparisons of means of subgroups were performed using least significant differences (LSD) test [33].

\section{Results and discussion}

In this study, K562 chronic leukemia cells were treated with grape seed oil and/or methotrexate in two different concentrations in culture medium at for 24 and 48 hours. In the end of 24 hour period, the ratio of live cells in all groups was found lower than that of control group. However, the only significant decrease was observed with MTX and MTX + GSOH groups. No statistically significant decrease was obtained between MTX and MTX + GSOH groups.

In the end of 48 hour period, similarly, the ratio of live cells in all groups were showed statistically significant decrease in comparison to the control group. The cell viability ratio of MTX+GSOH group was significantly lower than that of MTX group (Figure 1).

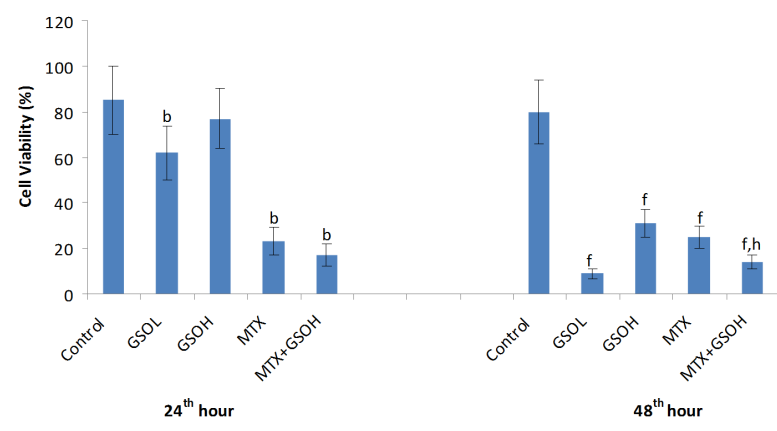

Figure 1. The cell viability ratios for $24^{\text {th }}$ and $48^{\text {th }}$ hours. Data were given as mean \pm standard deviation. b: significant decrease in comparison to control group $(24 \mathrm{hrs})(\mathrm{p}<0.05)$; f: significant decrease in comparison to control group (48 hrs) $(\mathrm{p}<0.05)$; h: Significant decrease in comparison to MTX group (48 hrs) $(\mathrm{p}<0.05)$.

In comparison to the control group, 24 hours after GSOH treatment, CAT, SOD, PON1, and ARE levels increased ( $\mathrm{p}<0.05$ ) whereas MDA levels remained unchanged. Under the same conditions, SOD, PON and ARE levels showed increase upon GSOL treatment $(\mathrm{p}<0.05)$, but MDA and catalase levels didn't change significantly. In contrast, 24 hours after MTX treatment any change in any of these parameters was not observed. However, MTX + GSO combination treatment resulted in increasing SOD and ARE values in comparison to control group, but MDA levels were lower than those obtained upon MTX treatment alone (Figures 2-6).

All these parameters regarding antioxidant activity were also measured after 48 hours of treatment. The data were evaluated in comparison to those obtained from control group. GSOH treatment showed increase in SOD, PON and ARE levels $(\mathrm{p}<0.05)$, but CAT and MDA levels remained unchanged. GSOL treatment cause increase in catalase, SOD, PON and ARE levels $(\mathrm{p}<0.05)$, but didn't resulted in any change at MDA levels. In contrast, MTX treatment caused significant increase in MDA levels in comparison to control group $(\mathrm{p}<0.05)$. In case of combination treatment, PON levels increased compared to control group. SOD levels were significantly higher than both control and MTX groups. However, MDA levels considerably decreased in comparison to MTX group (Figures 2-6).

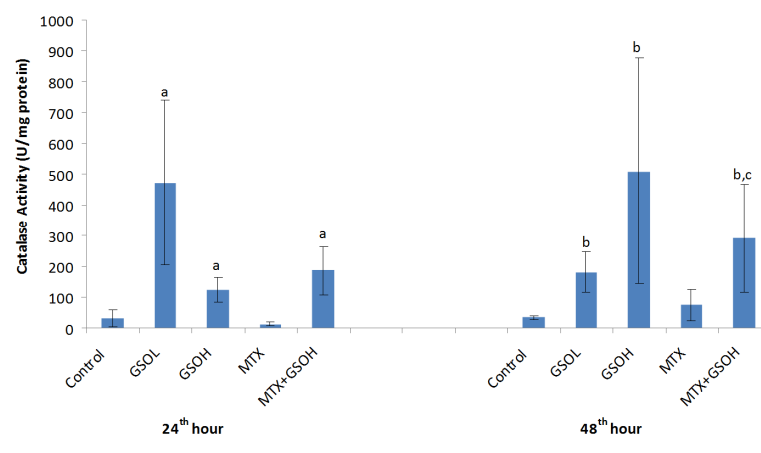

Figure 2. CAT activities of cell homogenates in the end of 24 and 48 hour periods. Data were given as mean \pm standard deviation. a: significant increase in comparison to control group $(24 \mathrm{hrs})(\mathrm{p}<0.05)$; b: Significant increase in comparison to control group ( $48 \mathrm{hrs})(\mathrm{p}<0.05)$; c: significant increase in comparison to MTX group ( $48 \mathrm{hrs})(\mathrm{p}<0.05)$.

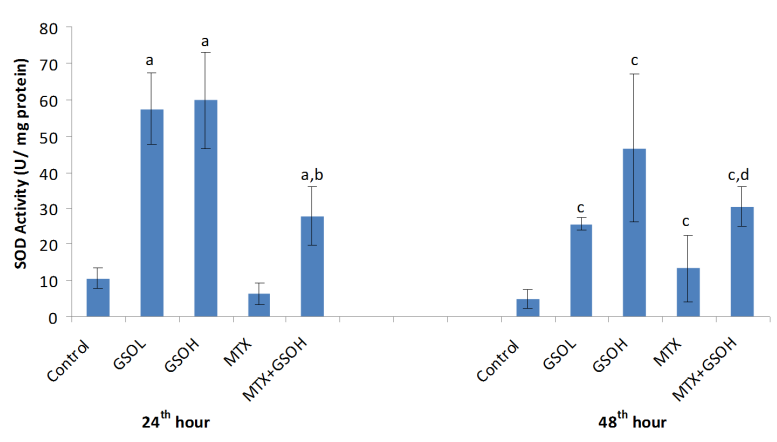

Figure 3. SOD activities of cell homogenates in the end of 24 and 48 hour periods. Data were given as mean \pm standard deviation. a: significant increase in comparison to control group $(24 \mathrm{hrs})(\mathrm{p}<0.05)$; b: Significant increase in comparison to MTX group $(24 \mathrm{hrs})(\mathrm{p}<0.05)$; : Significant increase in comparison to control group $(48 \mathrm{hrs})(\mathrm{p}<0.05)$; d: Significant increase in comparison to MTX group ( $48 \mathrm{hrs})(\mathrm{p}<0.05)$.

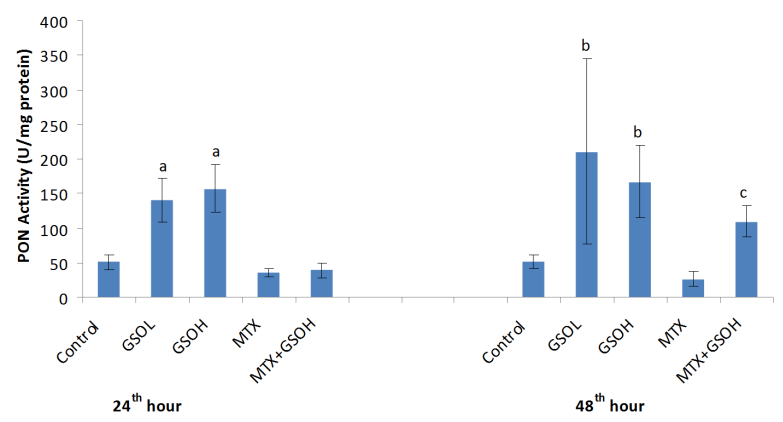

Figure 4. PON activities of cell homogenates in the end of 24 and 48 hour periods. Data were given as mean \pm standard deviation. a: Significant increase in comparison to control group $(24 \mathrm{hrs})(\mathrm{p}<0.05)$; b: Significant increase in comparison to control group $(48 \mathrm{hrs})(\mathrm{p}<0.05)$; c: Significant increase in comparison to MTX group ( $48 \mathrm{hrs})(\mathrm{p}<0.05)$.

Recent studies on toxicity of anticancer drugs have focused on oxidative stress $[4,6,8]$. Oxidative stress was held responsible for the mechanism of adverse reactions of MTX in liver, kidney, small intestine, central nervous system, and hematopoietic system $[6,8]$. Babiak et al. showed that MTX reduces glutathione levels, a significant antioxidant of human organism, in HeLa cells [4]. In the study of Jahovic et al., myeloperoxidase activities and MDA levels increased upon single dose i.p. administration of MTX in the blood, liver and 
kidney tissues of rats whereas glutathione levels decreased [8]. Similarly, in another study of Jahovic et al., reduction in glutathione levels in the rat small intestine and increase in MDA levels were determined as side effects [6]. They claimed that oxidative stress plays a significant role in the damage caused by MTX in small intestine. Miyazono et al. related oxidative damage formed in small intestine of rats by intravenous administration of MTX to myeloperoxidase activity, which is the indicator of neutrophil infiltration [3]. Cetiner et al. found a significant increase in myeloperoxide activity, collagen content, and lipid peroxide levels along with a decrease in glutathione levels in hepatic, renal, and intestinal tissues due to the toxic effect of MTX [2]. In addition, increase in serum cytokine TNF- $\alpha$ levels and systemic inflammatory response with histological analysis were determined [2]. Similarly, Devrim et al. revealed the significant role of oxidative stress in MTX nephrotoxicity [5]. Uz et al. reported an increase in NO levels of renal tissues of MTX treated rats [7].

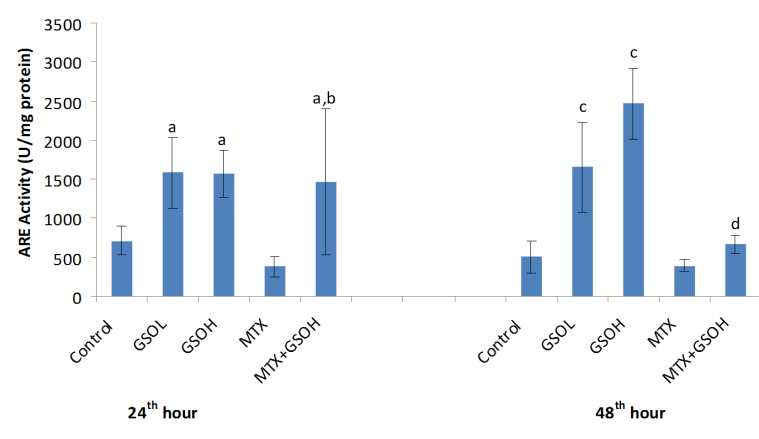

Figure 5. ARE activities of cell homogenates in the end of 24 and 48 hour periods. Data were given as mean \pm standard deviation. a: Significant increase in comparison to control group $(24 \mathrm{hrs})(\mathrm{p}<0.05)$; b: significant increase in comparison to MTX group $(24 \mathrm{hrs})(\mathrm{p}<0.05)$; $\mathrm{c}$ : Significant increase in comparison to control group ( $48 \mathrm{hrs})(\mathrm{p}<0.05)$; d: Significant increase in comparison to MTX group $(48 \mathrm{hrs})(\mathrm{p}<0.05)$.

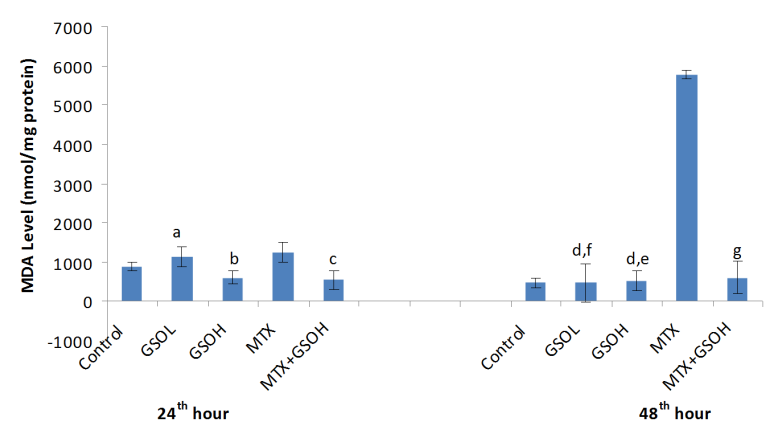

Figure 6. MDA levels of cell homogenates in the end of 24 and 48 hour periods. Data were given as mean \pm standard deviation. a: Significant increase in comparison to control group $(24 \mathrm{hrs})(\mathrm{p}<0.05)$; b Significant decrease in comparison to control group $(24 \mathrm{hrs})(\mathrm{p}<0.05)$; c: Significant decrease in comparison to MTX group (24 hrs) $(\mathrm{p}<0.05)$; d: Significant decrease in comparison to MTX group (48 hrs) $(p<0.05)$; e: Significant increase in comparison to control group ( $48 \mathrm{hrs})(\mathrm{p}<0.05)$; f significant decrease in comparison to control group (48 hrs) $(\mathrm{p}<0.05)$; g: Significant increase in comparison to control group ( $48 \mathrm{hrs})(\mathrm{p}<0.05)$.

Although there are numerous in vivo studies indicating oxidative stress caused by MTX in various organs and systems, number of in vitro studies are limited [2]. In this study, antioxidant enzyme activities and lipid peroxidation products were investigated at 24 and 48 hours treatment periods following MTX administration to K562 leukemia cells. K562 cells are so convenient for studies conducted in order to understand the organization of hematopoietic cells. At the 24 hour time point of MTX treatment, reduction in CAT, SOD, PON, and ARE enzyme activities was determined, whereas an increase was found in MDA levels.

At the 48 hour time point of MTX treatment, an increase in CAT and SOD activities were found in comparison to those obtained at $24^{\text {th }}$ hour. At the same time point, PON activities showed decrease while ARE activities statistically insignificant increase. In the end of 48 hours, MDA activity showed a dramatic increase. As the ratio of the viability of K562 leukemia cells' concerned, in the end of the first 24 hour treatment period, $73 \%$ of reduction was determined in MTX treated cells. In the end of the second 24 hour period, this ratio was found as $69 \%$. Although the survival rate of the cells at the $48^{\text {th }}$ hour is rather lower than that obtained at the $24^{\text {th }}$ hour, the difference between them is not statistically significant. This may be due to the resistance of leukemia cells to MTX.

Based on data, it may be claimed that antioxidant systems of MTX treated K562 leukemia cells within 24 hours and then, in the next 24 hour period, antioxidant system re-activated itself, trying to preserve the antioxidant-lipid peroxidation balance. It can also be stated that decrease in PON activity is due to enzyme inhibition as a result of increased lipid peroxidation.

Even though the increase in lipid peroxidation as a result of MTX treatment to cancer cells is not favorable, it is significantly important for an ideal therapy [2,7] because cells undergo apoptosis as a result of the increase in oxidative load and hence, complete remission is obtained $[2,7,8]$. The most important matter is that this increase should not cause oxidative stress in healthy cell [7]. Therefore, proper balance between lipid peroxidation and antioxidants should be maintained in the cells because of their potential importance in the pathogenesis of various pathologic diseases such as cancer. Administration of antioxidants along with cytotoxic agents (e.g. MTX) may be useful [2,6,7].

Al Attar et al. added grape seed oil into daily diets of rana ridibunda frogs exposed to 7,12-dimethylbenz[a]anthracene (DMBA) to prevent hepatotoxicity [34]. Protective effect of grape seed oil for liver damage was found [34]. Maheswari et al. reported that grape seed oil acts protective against hazardous effect of carbon tetrachloride $\left(\mathrm{CCl}_{4}\right)$ in liver cells. They showed that this is due to antioxidant activity of high vitamin E composition of grape seed oil [35].

In our study, low concentration of grape seed oil significantly increased CAT, SOD, PON and ARE activities of K562 leukemia cells within 24 hours of treatment, whereas MDA levels decreased approx. $31.5 \%$. However, this decrease is not statistically significant. Similarly, high concentration of grape seed oil caused the similar effect on CAT, SOD, PON, and ARE activities within the same treatment period. However, its effect on MDA level was in contrast, increasing it approx. $27.48 \%$. This wasn't statistically significant. Furthermore, in the end of 24 hour period, the comparison of K562 cell lines treated with high and low concentrations of grape seed oil indicated that catalase activity of GSOH group is significantly higher than that of GSOL group. No significant difference was found in SOD, PON, and ARE activities of these two groups. MDA level showed increase in GSOH group in comparison to GSOL group. CAT activity of GSOH group was significantly higher than that of GSOL group. No significant difference was found in SOD, PON, and ARE activities. MDA levels of GSOH group were much higher than control group. This indicates that low dose grape seed oil increased the antioxidant parameters in the end of $24^{\text {th }}$ hour and thus, may play a significant role in preventing lipid peroxidase. Also, it can be stated that high dose grape seed oil can relatively less enhance antioxidant enzyme activities, but dramatically increase lipid peroxidation. The reason behind that is not clear yet. It might be due to rapidly enhanced cell death.

In the end of 24 hour period, viability ratios of K562 leukemia cells were found decreasing $27.05 \%$ with high dose grape seed oil treatment while it was $9.4 \%$ for low dose treated 
cells. In addition, viability of K562 cells $88.75 \%$ decreased upon high dose grape seed oil administration whereas this decrease was $61.25 \%$ with low dose GSO application after 48 hours. This indicated that high dose grape seed oil is more efficient on K562 leukemia cells in the end of the 48 hour treatment period.

At the $48^{\text {th }}$ hour, lower dose grape seed oil significantly increase CAT, SOD, PON, and ARE activities in K562 leukemia cells. MDA level increased approx. $11.8 \%$, but this wasn't found statistically significant. On the other hand, high dose grape seed oil treatment caused significant increase in CAT, SOD, PON, and ARE activities, but not changed MDA levels.

Upon comparison of the effects of high and low dose grape seed oil treatments on K562 leukemia cells in the end of 48 hour period, the CAT, SOD, and ARE enzyme activities of GSOH group was found to be higher. PON activities were lower. However, MDA level reached the highest level in GSOL group in comparison to both GSOH and control groups. This indicates that low dose grape seed oil increase antioxidant parameters at a much more extent and interestingly, this causes even a slight increase in lipid peroxidation. On the other hand, high dose grape seed oil treatment enhances antioxidant enzyme activities at a relatively low extent, but in contrast to the data obtained at $24^{\text {th }}$ hour, does not change lipid peroxidation.

Based on data, it can be stated that high dose grape seed oil might be the potentially effective therapy for K562 leukemia cells, concerning antioxidant enzyme activities, lipid peroxidation levels, and cell viability ratios in the end of 48 hour treatment.

High dose grape seed oil possessing oxidative stress reducing and leukemia cell destroying properties might raise a hope for prevention of constantly raising oxidative stress in MTX treated leukemia cells. It has been unclear that whether the combinatorial use of MTX and grape seed oil causes a cumulative or an inhibitory effect. With this in mind, the effect of high dose grape seed oil was investigated in these studies.

In the end of $24^{\text {th }}$ hour, CAT, SOD and ARE activities of MTX + GSOH group was statistically higher than those of MTX and the control groups. While PON activity was insignificantly increased, MDA level was found to be statistically lower.

In the end of $48^{\text {th }}$ hour, CAT, SOD, and PON activities of MTX + GSOH group were statistically higher in comparison to MTX group. ARE activity increased slightly. Also, CAT, SOD and ARE activities of MTX + GSOH group was higher than those of the control group. MDA level was found to be statistically lower. This shows significance with approx. $90 \%$ reduction.

In the end of $24^{\text {th }}$ hour, the decrease in cell viability of MTX $+\mathrm{GSOH}$ treated group was $26 \%$ less than MTX treated group. It reduced $80 \%$ in comparison to the control group.

In the end of $48^{\text {th }}$ hour, the decrease in cell viability of MTX + GSOH treated group was $24 \%$ less than MTX treated group. It reduced $82.5 \%$ in comparison to the control group.

Upon comparison of the effects of high dose grape seed oil treatment on K562 leukemia cells treated with MTX at 24th and $48^{\text {th }}$ hours, a slight increase was obtained in the end of the $24^{\text {th }}$ hour in comparison to MTX treated group. Similar increase was observed in comparison to the control group in the end of the $4^{\text {th }}$ hour. However, this difference wasn't significant enough. Regarding oxidative stress parameters, sharp decline in MDA level and hence, lipid peroxidation was observed. This might indicate that 48 hours is the maximum efficient time period for grape seed oil treatment.

\section{Conclusion}

In conclusion, grape seed oil is efficient in reducing oxidative stress caused by MTX treatment. This is important as it will prevent cytotoxic effect on healthy cells and reduce severe side effects of chemotherapy. Thus, grape seed oil can be a good candidate of complementary therapy for leukemia.

\section{Acknowledgements}

Authors would like to thank Tüzün Yağ Ltd., (Tarsus, Mersin, Turkey) for providing grape seed oil. Bartosz Pomierny and Katarzyna Przejczowska are grateful to Erasmus Student Mobility Program enabling them to anticipate in this project. Authors would like to extent their gratitude to Assoc. Prof. Dr. Serap Yalin at Mersin University, Faculty of Pharmacy, Department of Biochemistry for useful discussions.

\section{References}

[1]. Cheah, K. Y.; Howarth, G. S.; Yazbeck, R.; Wright, T. H.; Whitford, E. J.; Payne, C.; Butler, R. N.; Bastian, S. E. Cancer Biol. Ther. 2009, 8, 382390.

[2]. Cetiner, M.; Sener, G.; Sehirli, A. O.; Eksioglu-Demiralp, E.; Ercan, F.; Sirvancl, S.; Gedik, N.; Akpulat, S.; Tecimer, T.; Yegen, B. C. Toxicol. Appl. Pharmacol. 2005, 209, 39-50.

[3]. Miyazono, Y. Gao, F.; Horie, T. Scand. J. Gastroenterol. 2004, 39, 11191127.

[4]. Babiak, R. M.; Campello, A. P.; Carnieri, E. G.; Oliveira, M. B. Cell Biochem. Funct. 1998, 16, 283-293.

[5]. Devrim, E.; Cetin, R.; Kilicoglu, B.; Erguder, B. I.; Avci, A.; Durak, I. Ren Fail. 2005, 27, 771-773.

[6]. Jahovic, N.; Sener, G.; Cevik, H.; Ersoy, Y.; Arbak, S.; Yegen, B. C. Cell Biochem. Funct. 2004, 22, 169-178.

[7]. Uz, E.; Oktem, F.; Yilmaz, H. R.; Uzar, E.; Ozguner, F. Mol. Cell Biochem. 2005, 277, 165-170.

[8]. Jahovic, N.; Cevik, H.; Sehirli, A. O.; Yegen, B. C.; Sener, G. J. Pineal Res. 2003, 34, 282-287.

[9]. Pinheiro, F. V.; Pimentel, V. C.; De Bona, K. S.; Scola, G.; Salvador, M. Funchal, C.; Moretto, M. B. Cell Biochem. Funct. 2010, 28, 89-94.

[10]. Pajuelo, D.; Diaz, S.; Quesada, H.; Fernandez-Iglesias, A.; Mulero, M.; Arola-Arnal, A.; Salvado, M. J.; Blade, C.; Arola, L. J. Agric. Food Chem. 2011, 59, 4279-4287.

[11]. Asha Devi, S.; Sagar Chandrasekar, B. K.; Manjula, K. R.; Ishii, N. Exp. Gerontol. 2011, 46, 958-964.

[12]. Jeronimo, E.; Alves, S. P.; Dentinho, M. T.; Martins, S. V.; Prates, J. A.; Vasta, V.; Santos-Silva, J.; Bessa, R. J. J. Agric. Food Chem. 2010, 58, 10710-10721.

[13]. Vossen, E.; Ntawubizi, M.; Raes, K.; Smet, K.; Huyghebaert, G.; Arnouts, S.; De Smet, S. J. Anim. Physiol. Anim. Nutr. 2011, 95, 198-205.

[14]. Asadi, F.; Shahriari, A.; Chahardah-Cheric, M. Food Chem. Toxicol. 2010, 48, 2454-2457.

[15]. Li, W. G.; Zhang, X. Y.; Wu, Y. J.; Tian, X. Acta Pharmacol. Sin. 2001, 22 1117-1120.

[16]. Belviranl,, M.; Gokbel, H.; Okudan, N.; Basarali, K. Brit. J. Nutr. 2011, 20, 1-8.

[17]. Feringa, H. H.; Laskey, D. A.; Dickson, J. E.; Coleman, C. I. J. Am. Diet Assoc. 2011, 111, 1173-1181.

[18]. Salem, N. A.; Salem, E. A. Ren. Fail. 2011, 33, 824-832.

[19]. Radhakrishnan, S.; Reddivari, L.; Sclafani, R.; Das, U. N.; Vanamala, J. Front. Biosci. (Elite Ed) 2011, 3, 1509-1523.

[20]. Kaur, M.; Tyagi, A.; Singh, R. P.; Sclafani, R. A.; Agarwal, R.; Agarwal, C. Mol. Carcinog. 2011, 50, 553-562.

[21]. Park, S. Y.; Lee, Y. H.; Choi, K. C.; Seong, A. R.; Choi, H. K. Lee, O. H.; Hwang, H. J.; Yoon, H. G. J. Med. Food 2011, 14, 9-16.

[22]. Dinicola, S.; Cucina, A.; Pasqualato, A.; Proietti, S.; D'Anselmi, F.; Pasqua, G.; Santamaria, A. R.; Coluccia, P.; Laganà, A.; Antonacci, D.; Giuliani, A.; Bizzarri, M. Br. J. Nutr. 2010, 104, 824-832.

[23]. Song, X.; Siriwardhana, N.; Rathore, K.; Lin, D.; Wang, H. C. Mol. Carcinog. 2010, 49, 450-463.

[24]. Sharma, S. D.; Meeran, S. M.; Katiyar, S. K. Mol. Cancer Ther. 2010, 9 , 569-580.

[25]. Sharma, S. D.; Katiyar, S. K. Pharm. Res. 2010, 27, 1092-1102.

[26]. Gao, N.; Budhraja, A.; Cheng, S.; Yao, H.; Zhang, Z.; Shi, X. Clin. Cancer Res. 2009, 15, 140-149.

[27]. Hong, H.; Yin-Min, Q. Chin. Med. J. 2006, 119, 417-421.

[28]. Aebi, H. Methods Enzymol. 1984, 105, 121-126.

[29]. Sun, Y.; Oberley, L. W.; Ying, L. Clin. Chem. 1988, 34, 497-500.

[30]. Eckerson, H. W.; Romson, J.; Wyte, C.; La Du, B. N. Am. J. Hum. Genet. 1983, 35, 214-227.

[31]. Yagi, K. Methods Mol. Biol. 1998, 108, 107-110.

[32]. Lowry, O. H.; Rosebrough, N.; Farr, A. L.; Randall, R. J. J. Biol. Chem. 1961, 193, 265-275.

[33]. Mansouri, E.; Panahi, M.; Ghaffari, M. A.; Ghorbani, A. Iran. Biomed. J. 2011, 15, 100-106.

[34]. Al Attar, A. M. Pakistan J. Nutr. 2004, 3, 304-309.

[35]. Maheswari, U. M.; Rao, P. G. M. Indian J. Pharmacol. 2005, 37, 179-182. 